\title{
Amiodarone-Induced Pulmonary Toxicity in a Patient With Paroxysmal Atrial Fibrillation and Recurrence of Pulmonary Toxicity
}

\author{
Paroksismal Atriyal Fibrilasyonlu Hastada Amiodarona Bağlı Akciğer \\ Toksisitesi ve Rekürrensi \\ Nuri Köse ${ }^{1}$ Tarık Yıldırım² \\ ${ }^{1}$ Department of Cardiology, Yücelen Hospital, Muğla, Turkey \\ ${ }^{2}$ Department of Cardiology, Balıkesir University Faculty of Medicine, Balıkesir, Turkey
}

\begin{abstract}
Amiodarone is an effective anti-arrhythmic agent widely used for management of supraventricular and ventricular arrhythmias. Amiodarone-induced pulmonary toxicity is one of the most serious side effects of amiodarone therapy. Patients who have developed pulmonary toxicity usually present with nonspecific symptoms such as cough, dyspnea, fever, and weight loss. Radiologically, amiodarone toxicity can manifest as a focal lesion or diffuse interstitial abnormality. Treatment involves immediate discontinuation of amiodarone and administration of corticosteroids for prompt recovery. Because of its long elimination half-life, pulmonary toxicity may initially progress despite drug discontinuation and may recur upon steroid withdrawal. In this manuscript, we presented a 62 yearsold woman who developed pulmonary toxicity due to amiodarone therapy, recovered with corticosteroid therapy but relapsed after stopping this therapy, and finally recovered completely after long term use of steroid therapy.

Key Words: Amiodarone; atrial fibrillation;cardiomyopathy; hypertrophic; toxicity.
\end{abstract}

\section{Objective}

Amiodarone hydrochloride (amiodarone) is a benzofuran-derived, iodine-rich drug. It was first used as an anti-anginal drug in 1960s. Later, it has been frequently used in the treatment of atrial and ventricular arrhythmias as a class III antiarrhythmic agent (1). When amiodarone is compared with other antiarrhythmic drugs, it has significant side effects although it is an effective drug. Amiodarone-related side effects include hepatotoxicity, pulmonary toxicity, cardiotoxicity, thyroid dysfunction, skin photosensitivity and corneal microdeposits(2). Amiodaroneinducedpulmonarytoxicity (AIPT) is a major side effect that limits the use of this drug $(1,3)$.

\begin{abstract}
Özet
Amiodaron supraventriküler ve ventriküler aritmilerin tedavisinde yaygın olarak kullanılan etkili birantiaritmikajandır. Amiodaron ilişkili pulmoner toksisite, amiodaron tedavisinin çok ciddi biryani etkisidir. Pulmonertoksisite gelişen hastalarda genellikle öksürük, nefesdarllğı, ateşve kilo kayb1 gibi nonspesifik semptomlar mevcuttur. Amiodarontoksisite siradyolojik olarak diffüzintertisyelan ormallikler ve yafokallezyonlar olarak görülebilir. Tedavi, amiodaronun derhal kesilmesi ve hızlı iyileşme için kortikosteroid verilmesini içerir. Amiodaronunuzun yarılanma ömrü nedeniyle pulmonertoksisite ilacin kesilmesine ragmen ilerleyebilir vesteroidin kesilmesi ile tekrarlayabilir. $\mathrm{Bu}$ yazıda, amiarontedavisine bağlı pulmonertoksisite gelişen ve kortikosteroid tedavisi ile iyileşen, tedavinin erken kesilmesi ile nüks gelişen ve steroid tedavisinin uzun sure kullanılması ile tam iyileșen 62 yaşında bir kadın hastay1 sunduk.
\end{abstract}

Anahtar Kelimeler: Amiodaron; atriyalfibrilasyon; hipertrofik; kardiyomiyopati; zehirlilik.

\section{Case Report}

A 62-year-old female patient presented with a history of progressive shortness of breath, fatigue, and dry cough. The patient had apical hypertrophic cardiomyopathy (Figure 1), and using amiodarone for rhythm control due to paroxysmal atrial fibrillation for 39 months (Figure 2). Initially, $900 \mathrm{mg}$ intravenous loading dose was administered in the first two days. Later on, she constantly took $200 \mathrm{mg} /$ day oral dose. In addition, she was taking $100 \mathrm{mg} /$ day oral metoprolol succinate, $160 \mathrm{mg} /$ day valsartan and warfarin treatment. Sinus rhythm was regained twice by electrical cardioversion due to the atrial fibrillation episodes during this time. The patient 


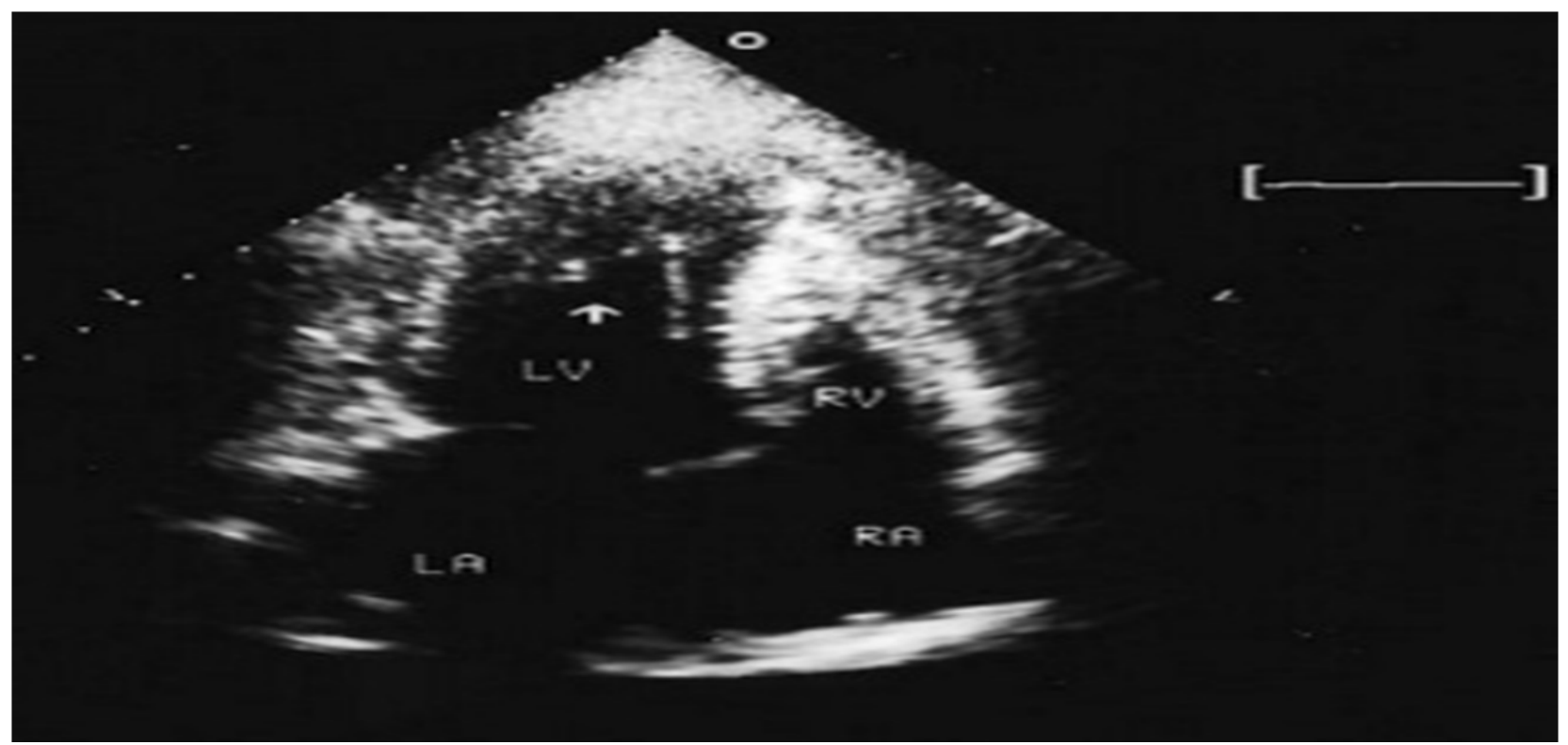

Figür 1. Left ventricle apical hypertrophy (arrow), and left atrial dilatation on the apical-4-chamber section of transthoracic echocardiography.

was asymptomatic and routine clinical evaluation was normal in the last examination three months ago.

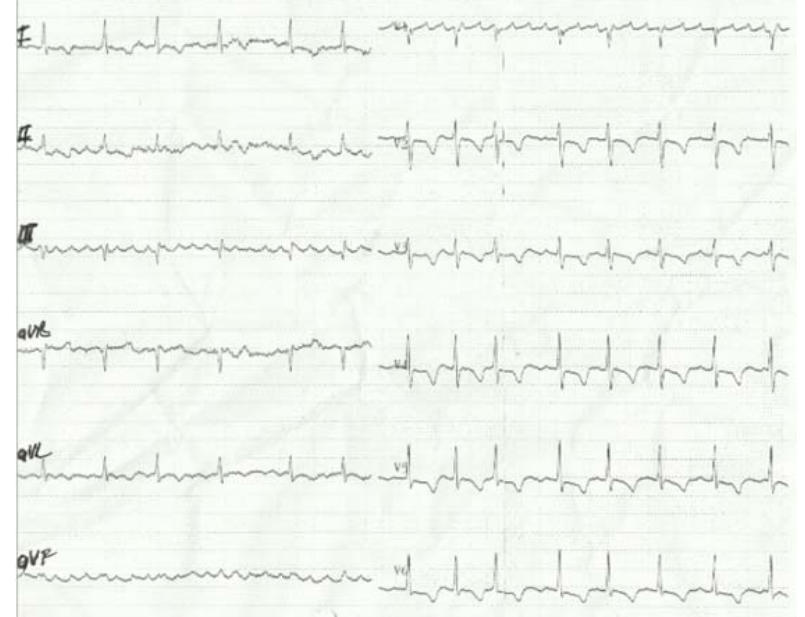

Figür 2. 12-lead electrocardiogram on the first day of admission revealed atral fibrillation.

Physical examination revealed that fever was 37.0 ${ }^{\circ} \mathrm{C}$, blood pressure was $130 / 80 \mathrm{mmHg}$ on the right arm, radial pulse was $91 \mathrm{bpm}$ and rhythmic, respiratory rate was $22 / \mathrm{min}$ and the patient had respiratory distress and diffuse crackles in both lungs. The oxygen saturation was $86 \%$ in pulse oximetry. $\mathrm{pH}$ was $7.51, \mathrm{PaO}_{2}$ was $62 \mathrm{mmHg}$ and $\mathrm{PaCO}_{2}$ was $26 \mathrm{mmHg}$ in arterial blood gas analysis. Normal sinus rhythm, a heart rate of 90 bpm, and anterior deep symmetrical T-wave inversion were present in the electrocardiogram. There was left ventricular apical hypertrophy in transthoracic echocardiography, left ventricular ejection fraction was normal and did not differ from previous echo reports. Posterior-anterior (PA) chest X-ray showed bilateral diffuse interstitial infiltrates (Figure 3A). High-resolution computed tomography (HRCT) also revealed multifocal ground-glass opacities and consolidation in both lungs (Figure 3B). Complete blood count and biochemistry analyses revealed white blood cells $10.1 \times 10^{3} \mathrm{uL}$ of (4-11), eosinophils $14.8 \%(0-5)$, lactate dehydrogenase 520 IU / L (0-450), C-reactive protein 62.02 $\mathrm{mg} / \mathrm{dL}(0-10)$, and erythrocyte sedimentation rate $89 \mathrm{~mm} / \mathrm{s}(0-20)$. Other routine biochemistry tests including thyroid, liver and renal function tests were normal. Patient's history, clinical, radiological and laboratory findings were evaluated and the patient was diagnosed with interstitial pneumonia which is a form of AIPT.The patient was admitted to hospital, amiodarone treatment was discontinued and $1 \mathrm{mg} / \mathrm{kg}$ dose of intravenous methylprednisolone was started. Thedose of metoprololsuccinatetakenbythepatientwasincrease d.A week later, the clinical findings were partially disappeared and the patient was discharged with the same dose of oral corticosteroids. Obvious clinical improvement was seen after1 month of follow-up. Improvedlung 


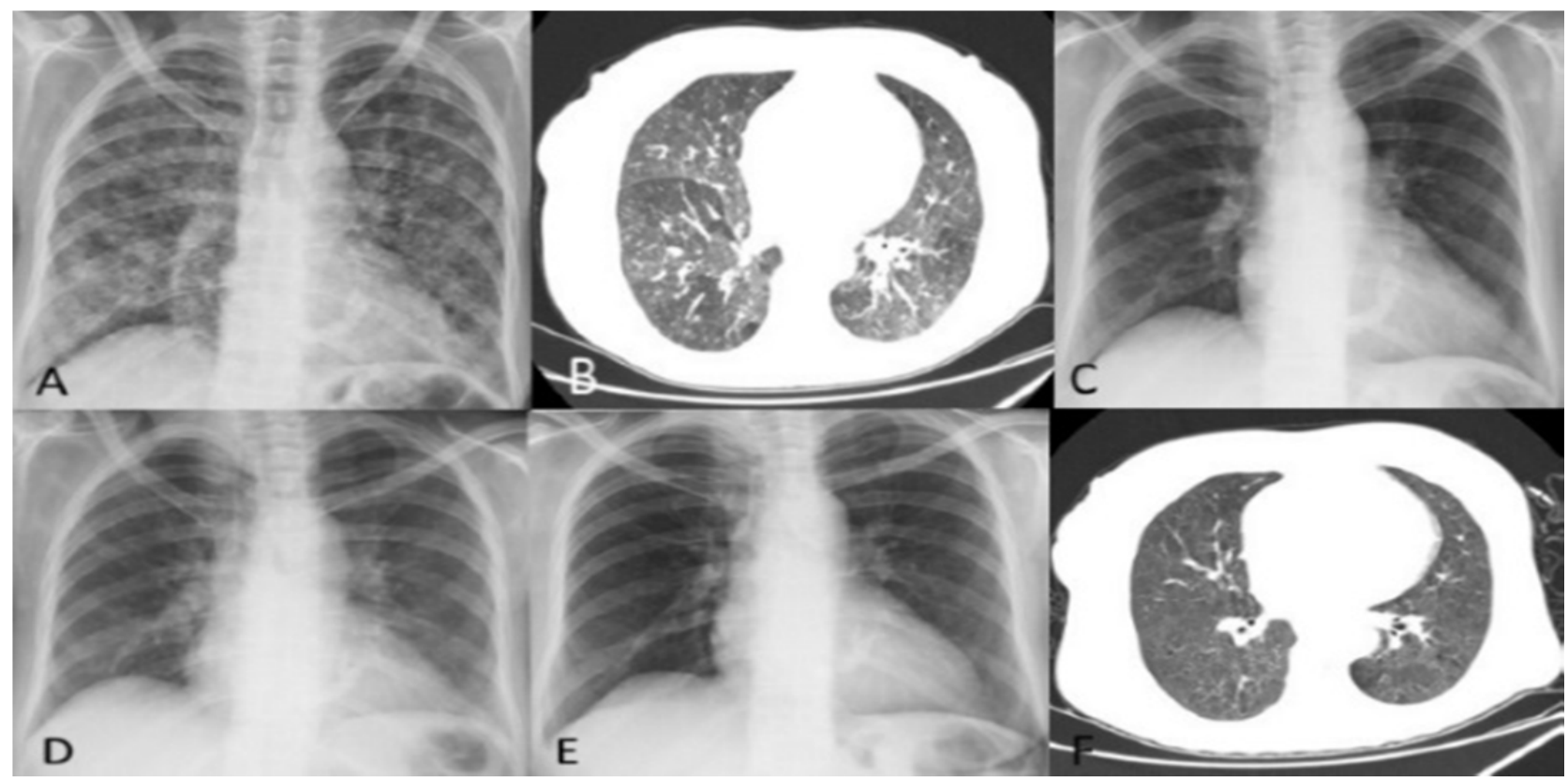

Figür 3. A. Bilateral diffuse interstitial infiltrates on chest X-ray at admission; B.Diffuse bilateral ground-glass opacities and consolidations on HRCT; C. Marked reduction of the diffuse interstitial infiltrates on chest roentgenogram at $3^{\text {th }}$ month of treatment; D. Increased diffuse interstitial infiltrates due to relapse on chest roentgenogram; E. Complete loss of diffuse interstitial infiltrates on chest roentgenogram at $6^{\text {th }}$ month of treatment; F. No bilateral ground-glass opacities or consolidation focuses on HRCT at $9^{\text {th }}$ month.

lesions were found in PA chest radiograph taken in the third month (Figure 3C), butwenoticedthattheheartrhythym of thepatientwasatrialfibrillationandweselected rate controlstrategy. The patient's control blood biochemical parameters were measured and they were normal. In the third month of treatment, the dose of steroids was gradually reduced by 4 $\mathrm{mg} /$ day dose. However, two weeks later shortness of breath and dry cough started again and widespread crackles appeared in the examination of both two lungs. White blood cells $6.9 \times 10^{3} \mathrm{uL}$, eosinophils $34.7 \%$, lactate dehydrogenase 430 $\mathrm{IU} / \mathrm{L}, \mathrm{C}$-reactive protein $6.05 \mathrm{mg} / \mathrm{dL}$, erythrocyte sedimentation rate $24 \mathrm{~mm} / \mathrm{s}$ were determined in biochemistry analyses. Diffuse interstitial infiltrates were observed in PA graph (Figure 3D). Corticosteroids were increased to the starting dose and the clinical follow-up of the patient improved (Figure $3 \mathrm{E}$ ). Improvement of the lung findings of pulmonary toxicity were observed on the $9^{\text {th }}$ month HRCT (Figure 3F). Steroid dose was gradually decreased and completely cut-off 12 months after the initiation, and no recurrence was observed in the follow-up.

\section{Discussion}

Amiodarone is a drug with a long half-life of about 30 to 108 days. Active metabolite of amiodarone accumulates in the lipid- rich tissues such as lung parenchyma (4). The mechanism of AIPT development remains unclear. Although it is focused on direct cytotoxic effect on lung and hypersensitivity reactions, it is thought to be multifactorial $(5,6)$. Amiodarone can cause cell damage producing free radicals. The focus is on the possibility of interaction of amiodarone with high-dose oxygen in the development of AIPT, which appears immediately after cardiopulmonary surgery in patients taking amiodarone (1). The age of the patient, dosing and pharmacokinetics, patient's lung characteristics, concomitant medication use, previous operations and pulmonary angiography may be effective in the AIPT development $(1,5)$. Ethnic factors and genetic structures may also play a role. AIPT can be seen in patients even after onset of treatment, or may develop due to chronic use, months or years after initiation (5). The risk is higher with doses higher than $400 \mathrm{mg} /$ day for more than 2 months, or $200 \mathrm{mg} /$ day doses for 2 years (4). However, it may also develop when using 200 $\mathrm{mg} /$ day and lower doses $(1,7)$. AIPT incidence is reported as $5-15 \%$ (8). Nonspecific symptoms such as fatigue, deteriorations in general status, cough, shortness of breath, weight loss, sometimes fever, pleuritis, pleural effusion may be seen in patients with AIPT. These symptoms may 
also be masked by the underlying heart or lung disease, and can cause a delay in diagnosis. In case of a shortness of breath occurring alone or accompanying other symptoms such as coughing in a patient taking amiodarone, the development of AIPT should be suspected. In severe cases, respiratory distress, hypoxemia and diffuse crackles can be determined. In patients rapidly presenting progressive diffuse pneumonia and respiratory failure, acute respiratory distress syndrome (ARDS) can develop (4). AIPT has various forms such as interstitial pneumonia, organizing pneumonia, solitary pulmonary mass and ARDS (6). Patients with suspected AIPT are diagnosed by combining history, clinical and radiological findings after excluding the alternative diagnoses. Response to the steroid treatment and cessation of the amiodarone also supports the diagnosis. The differential diagnosis of AIPT should include pulmonary edema, infectious pneumonia, pulmonary thromboembolism, other restrictive lung diseases $(5,6)$. Increased erythrocyte sedimentation rate and lactate dehydrogenase, and leukocytosis can be detected in the laboratory analyses (6). Chest X-ray may reveal patchy or diffuse bilateral infiltrates dominant on the right side. Pleural thickening, pleural effusion, multiple pulmonary nodules were described in upper lobes due to iodine accumulation in the type II pneumocytes. Ground-glass opacities can be seen at HRCT. Restrictive or mixed obstructive / restrictive pattern can be detected in pulmonary function tests (4). None of the chest computed tomography, gallium scintigraphy and respiratory function test results are specific. Bronchoalveolar lavage and transbronchial biopsy may be useful in diagnosis. The presence of foam macrophages support the diagnosis in pathological examination but is not diagnostic. The decrease of diffusion capacity of carbon monoxide more than $15 \%$ is a strong indicator for AIPT in a patient using amiodarone (5). The serum concentrations of KL-6, which is a mucin-like high molecular weight glycoprotein that released from proliferating type II pneumocytes, is a promising indicator for the diagnosis of AIPT $(6,9)$. In our case, the regular follow-up made the diagnose earlier. The primary treatment of AIPT is immediate cessation of amiodarone. Only discontinuing the drug may be sufficient in mild cases. Steroids should be given to the patients with pulmonary parenchymal involvement in imaging studies regardless of the presence of hypoxemia. This treatment strategy allows early recovery and reduces parenchymal fibrosis. Clinical symptoms usually disappear within 3-4 weeks, but the normalization of the radiological findings and the improvement of lung functions may take a longer time, such as 18 months. In our case, amiodarone dose was gradually reduced by the reason of rapid clinical improvement in the third month. However, pulmonary toxicity recurred in the follow-up. Because of long half-life of amiodarone and pulmonary deposition in adipose tissue, the pulmonary toxicity may progress despite discontinuation of drug and may recur after cessation of steroids (6). Therefore, the drug therapy should be continued for at least for 4-12 months and the dose should be gradually reduced to avoid relapse $(1,10)$. Timely treated cases can be fully cured with good prognosis (11). Pulmonary fibrosis may develop with delays in treatment or in therapy-resistant patients and severe cases can result with death (1). The mortality is around $10 \%$ in patients with AIPT, and higher at those with ARDS as 50\% $(10,12)$.

Consequently, AIPT can be totally cured with early diagnosis and suitable treatment. Immediate cessation of amiodarone and initiation of corticosteroids constitute the basis for treatment. Each patient using amiodarone should be periodically followed-up in terms of AIPT and other side effects. We aim to highlight that recurrence can develop in cases in which steroid treatment is ceased early or reduced, due to the long elimination of half-life of amiodarone.

Peer-review: Externally peer-reviewed.

Conflicts of interest: We have no conflict of interest to declare

Informed consent: Written informed consent was obtained from the patient for the publication of the case report and the accompanying images.

Institutional review board statement: Ethical review and approval were waived for this study because our institution does not require these for case reports.

Funding: This research received no external funding.

Authorship contributions: Concept: N.K., T.Y.; Design: N.K., T.Y.; Supervision: NK.,TY.; Material: N.K.; Data: N.K., T.Y.; Literature search: N.K., T.Y.; Data collection: N.K.; Writing: N.K.; Critical revision: T.Y.

\section{References}

1. Van Cott TE, Yehle KS, DeCrane SK, Thorlton JR. Amiodarone-induced pulmonary toxicity: case study with 
syndrome analysis. Heart Lung 2013;42(4):262-266.

2. Fadahunsi O, Krol R. Acute amiodarone pulmonary toxicity following lung resection. Int J Biomed Sci 2014;10(3):217-220.

3. Garg J, Agrawal N, Marballi A, Agrawal S, Rawat N, Sule S, et al. Amiodarone induced pulmonary toxicity: An unusual response to steroids. Am J Case Rep 2012;13:62-65.

4. Nacca N, Bhamidipati CM, Yuhico LS, Pinnamaneni S, Szombathy T. Severe amiodarone induced pulmonary toxicity. J Thorac Dis 2012;4(6):667-670.

5. Lee W, Ryu DR, Han SS, Ryu SW, Cho BR, Kwon H, et al. Very early onset of amiodarone-induced pulmonary toxicity. Korean Circ J 2013;43(10):699-701.

6. Schwaiblmair M, Berghaus T, Haeckel T, Wagner T, von Scheidt W. Amiodaroneinduced pulmonary toxicity: an underrecognized and severe adverse effect? Clin Res Cardiol 2010;99(11):693-700.

7. Ott MC, Khoor A, Leventhal JP, Paterick TE, Burger CD. Pulmonary toxicity in patients receiving low-dose amiodarone. Chest 2003;123(2):646-651.
8. Okayasu K, Takeda Y, Kojima J, Yoshizawa A, Kobayashi N, Sugiyama H, et al. Amiodarone pulmonary toxicity: a patient with three recurrences of pulmonary toxicity and consideration of the probable risk for relapse. Intern Med 2006;45(22):1303-1307.

9. Endoh Y, Hanai R, Uto K, Uno M, Nagashima H, Narimatsu A, et al. KL-6 as a potential new marker for amiodaroneinduced pulmonary toxicity. Am J Cardiol 2000;86(2):229-231.

10. Yamada Y, Shiga T, Matsuda N, Hagiwara $\mathrm{N}$, Kasanuki $\mathrm{H}$. Incidence and predictors of pulmonary toxicity in Japanese patients receiving low-dose amiodarone. Circ J 2007;71(10):1610-1616

11. Fabiani I, Tacconi D, Grotti S, Brandini R, Salvadori C, Caremani $M$, et al. Amiodarone-induced pulmonary toxicity mimicking acute pulmonary edema. J Cardiovasc Med (Hagerstown) 2011;12(5):361-365.

12. Papiris SA, Triantafillidou C, Kolilekas L, Markoulaki D, Manali ED. Amiodarone: review of pulmonary effects and toxicity Drug Saf 2010;33(7):539-558. 